\title{
The influence of economic factors on the development of the project for the development of cruise transport in Russia
}

\author{
Denis Motorin ${ }^{1}$, Svetlana Morozova ${ }^{1}$, Anna Antonova ${ }^{2}$, Kseniya Pasternak $^{2}$, Alexandra \\ Radushinskaya $^{1, *}$, and Victoria Smirnova ${ }^{3,4}$ \\ ${ }^{1}$ St. Petersburg State University, 191104, ul. Chaykovskogo 62, St. Petersburg, Russia \\ ${ }^{2}$ Institute of Industrial Management, Economics and Trade, High School of Trade and Service, \\ 195251, ul. Politekhnicheskaya, 29, 3rd building, St Petersburg, Russia \\ ${ }^{3} \mathrm{Head}$ of special customs procedures of the skipper's customs post of the Baltic Customs, 199405, the \\ territory of the Nevskaya Guba Shore VO, 1A, St Petersburg, Russia \\ ${ }^{4}$ St. Petersburg Branch of the Russian Customs Academy named after V. B. Bobkov (Russian \\ Customs Academy), 52, Sofiyskaya st., St Petersburg, Russia
}

\begin{abstract}
The article examines the influence of global and local factors on the planning and implementation of large investment projects in the field of tourism in St. Petersburg. Analyzed the current and long-term political and economic factors that must be taken into account when developing a marketing concept for a cruise tourism project with a point of departure and end of routes in the city. The project includes the creation of an international cruise tourism center and a marine passenger shipping company, including the construction of a sea vessel. The negative influence of such factors as: political and economical confrontation with Western countries, aggravated in the period after 2014; restrictions on cross-border movements; increase in the audience of tourists from Southeast Asia. On the other hand, the implementation of the project can be favorably influenced by such factors as: internal political factors of competition between regional elites, the prevailing culture of cruise shipments on the Baltic Sea in the "ferry" format; the effect of replacing "shortfalls in foreign expenditures"; integration with the opening of the "Lakhta Center" and the direction of cinema tourism. An assessment was made of the degree of influence of these factors on the marketing concept of the project for the development of a cruise message and the terms of its payback.
\end{abstract}

\section{Introduction}

The new socio-economic situation in which the countries of the world find themselves in connection with the pandemic and restrictions on the movement of people, adopted in order to counter its spread, has a significant impact on the planning and implementation of large investment projects. During 2020, a number of trends emerged that may become

* Corresponding author: aleigrad@gmail.com 
decisive for the country's development in the near future. At the same time, these trends are closely related to the factors of the global economy and politics and have significant consequences for the development of many business sectors (national economy). Such trends and their consequences, in particular, include:

- the emergence of anti-epidemic barriers to the movement of citizens since the beginning of 2020 has become the basis for the narrowing and significant complication of the international aspect of the tourism industry and the hotel business (anti-epidemic barriers);

- the narrowing of the zone of conflict-free interaction against the background of the consolidation of the division "Russia (and allies)" / "Western Europe" in Eurasia due to the deepening political and economic contradictions between Russia and the United States, is fraught with the appearance of elements of the "iron curtain" in such areas as: investment, scientific -technical cooperation, tourism (narrowing the zone of conflict-free interaction);

- the sphere of remote interaction of buyers and sellers, employees and employers, and other types of contractors has been significantly expanded, which leads to an accelerated digitalization of their interaction channels, an increase in the degree of influence of the IT industry on everyday life (digitalization).

Along with global macroeconomic factors, local markets, the volume and structure of private and public investments are influenced by medium-term factors:

- demand is growing in some local markets, in which solvent consumers are trying to "master" the funds that they did not spend on their traditional expenses abroad (that could be named a kind of replacement for "shortfalls in foreign expenditures");

- competition among regional elites is intensifying, shaping their business image in the long-term perspective of the presidential elections in Russia, including on the basis of significant investment projects proposed for implementation in the region with a significant share of funding from federal funds.

This incomplete list of trends and their consequences characterizes the introduction of anti-epidemic restrictions against the background of growing international political tension and the reaction of the domestic market and political elites to the new conditions.

The relevance of this work is determined by the need to search for and justify the possibilities of state investment in projects where the "drop-down foreign expenditures" of the middle class could be involved for the period of preservation of anti-epidemic restrictions in the country, and in the long term after their cancellation. The implementation of significant projects can bring an additional effect not only from an economic point of view (Keynesian multiplier). The effect for federal and regional authorities may lie in the image, both internal and foreign policy component. Obtaining all types of effects is associated with the need to analyze the conditions for the functioning of local markets (individual market niches).

The authors consider the cruise tourism market (the object of research) to be one of such markets, which can be developed if new start and end points for domestic and international cruises are formed on the territory of Russia, in particular, in St. Petersburg. When developing a marketing concept for a cruise tourism project in Russia, it is necessary to take into account both current and long-term political and economic factors that can affect the social and economic situation as a whole and the formation of similar and competing local markets for "foreign cost substitution".

Thus, the purpose of this study is to identify political and economic factors that influence the marketing concept of a cruise line development project. The object of the research is a project for the development of cruise tourism with a start and end point for cruises in St. Petersburg. The subject of the research is to determine the degree of influence and consequences of short-term and long-term political and economic factors on the development of the marketing concept of the specified project. One of the results of the 
study may be the actualization of approaches to the development of large tourism projects in the country in the context of anti-epidemic restrictions.

Research methods include analysis and synthesis, expert judgment and generalization.

\section{Research materials}

Description of the project. As stated in the description, the main goal of the project is "to create a competitive world-class Russian tourist product for organizing year-round cruise traffic in the Baltic on the basis of the infrastructure of the port of the beginning and end of cruises in St. Petersburg and the Russian sea passenger shipping company, which is being created for the first time in the Russian Federation - LLC «Baltic Passenger Lines» (BPL) $[1,2]$. The project is planned to be implemented in 2020-2026. on the basis of the Passenger Port of St. Petersburg "Marine Facade" (The Marine Facade complex is managed by the Passenger Port of St. Petersburg Marine Facade JSC, whose shares are owned by St. Petersburg, and the Federal State Institution Directorate for the Construction and Operation of Rosgranitsa Facilities (Rosgranstroy). Four pavilions, which currently make up the active part of the complex called "Morskoy Vokzal", in different shares belong to the joint-stock company and the state. The federal part is managed by Rosgranstroy, as there are customs checkpoints in the pavilions. - URL: https://www.fontanka.ru/2020/11/12/69540518 (access date 30.11.2020)) by creating additional coastal infrastructure of the port of the beginning / end of cruises in St. Petersburg (the Center for Sea Cruise Tourism) and providing its "anchor" loading through the development of the activities of a domestic sea cruise company with its own fleet. It is planned to attract private and public investments for the project. The project includes 2 components - A and B (see below).

A. The Center for International Cruise Tourism is planned for construction on the alluvial territories of the Vasilievsky Island of St. Petersburg in 2022-2026. The facility is necessary to provide passengers and cruise ships starting and ending cruises in the port of St. Petersburg with a full range of world-class services, including: check-in for flights, baggage handling, ship chandler services, transport services and communication with transport hubs of the city, duty free-trade, social and business, MICE - and entertainment infrastructure (including those aimed at residents of St. Petersburg), hotels and catering (Fig. 1).

The Maritime Community Business Center (MARC) includes the following elements:

- Hotel for 250-300 rooms (designed and branded on the basis of associations of St. Petersburg as a part of Northern Europe);

- Interactive maritime museum and children's maritime educational, cultural and entertainment center (in broad integration with the facilities of the entertainment and educational zone "Lakhta Center");

- Showrooms for sea cruise companies with shops and shopping pavilions.

The total investment in part A is about RUB 12 billion, which is planned to be distributed as follows:

- borrowed funds - 72\% (banks, loans and investors in the implementation of the PPP format);

- federal funds (funds from the federal budget and special development funds, including ASI (ASI - Agency for Strategic Initiatives to Promote New Projects "(asi.ru) was established on August 11, 2011. ASI's supervisory board is headed by Russian President Vladimir Putin. ASI supports projects aimed at systemic changes in the field of improving the business climate and supporting innovation, education and training personnel, health and social services, regional and urban development. Among the ASI's key initiatives are the National Rating of the Investment Climate in the Regions, the Smarttek platform for 
sharing best practices, the 100 City Leaders program, a model for increasing innovative openness of large companies and the platform of the National Technology Initiative) - 25\%;

- property of the project initiator (JSC "Passenger Port of St. Petersburg - 3\%).
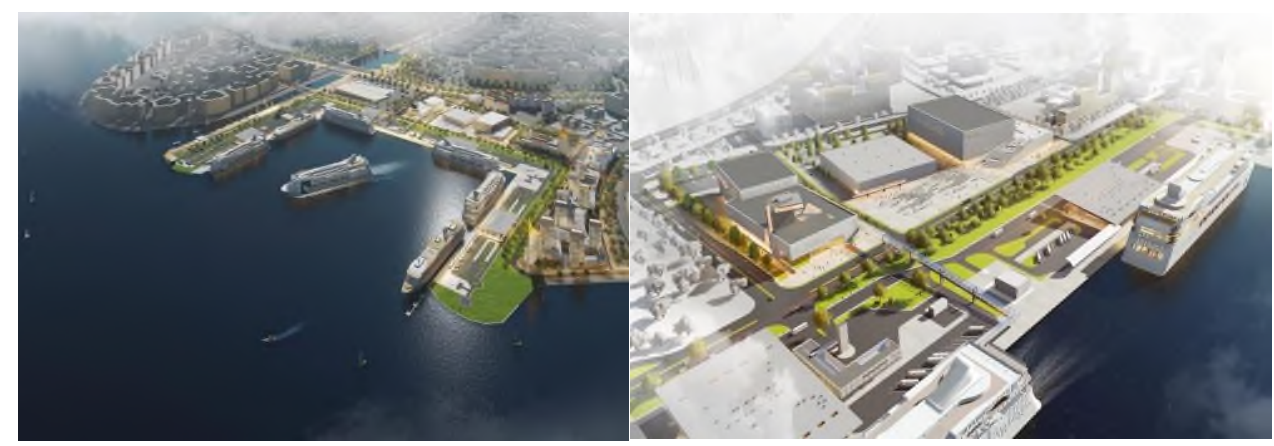

Fig. 1. Center for international cruise tourism and maritime public and business center in the alluvial territories [2].

B. Creation of a sea passenger shipping company, including the construction of a sea vessel, is a project that began in 2019 on the basis of Baltic Passenger Lines LLC (predesign work). From 2022, it is planned to launch year-round cruise routes of various lengths with rotation of directions from St. Petersburg to the Baltic ports (Fig. 2).

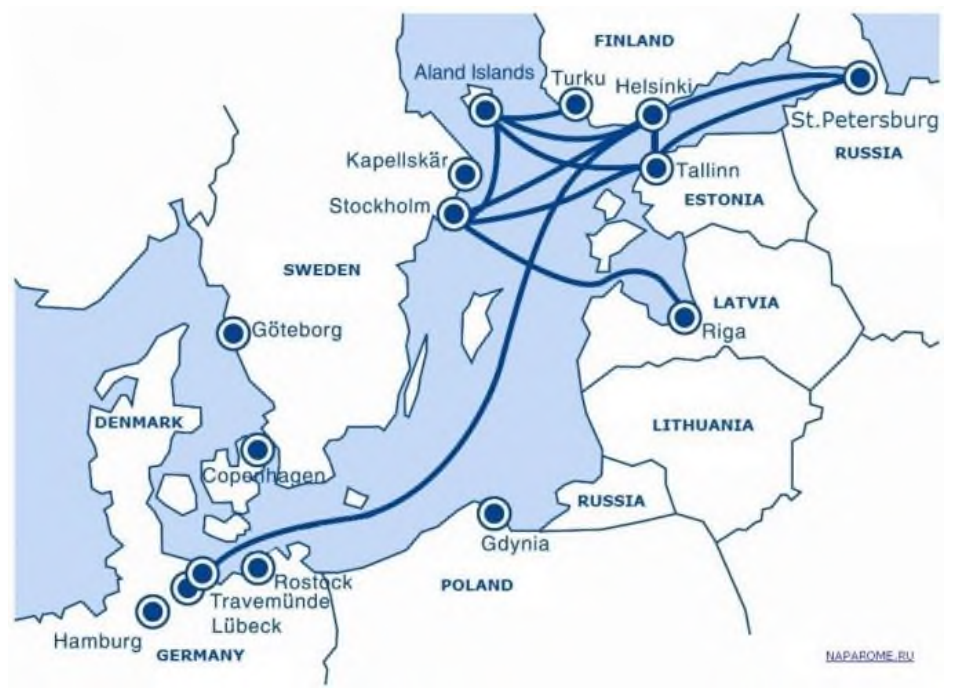

Fig. 2. The planned ports of call of the sea vessel in the framework of the activities of the Russian sea cruise company for the organization of cruise shipments in the Baltic with the beginning / ending in St. Petersburg [1,2].

For cruises, it is planned to use an ice-class passenger ship with a capacity of up to 2500 people. For the initial period, it is planned to use a chartered cruise liner, then, as funding sources are formed, it is planned to build (by 2026) its own domestic cruise ship at the Russian shipyards of USC (United Shipbuilding Corporation). For the first time, services on board will be targeted and customized to meet the needs of Russian tourists. At the same time, in general, the layout of a cruise ship - a ferry, traditional for the Baltic, can be preserved (Fig.3). 
It should be noted that in the Baltic Sea cruise transportation in terms of the number of passengers makes up about $15 \%$ of the global volume of cruise tourism services. At the same time, since the beginning of the 1990s, the development of ferry routes prevails on the Baltic routes - with the possibility of transporting cars. The Baltic Sea is the largest segment in the Northern European [3] market. However, the final decision on the vessel's design has not yet been made. Available options: ro - pax (allows you to carry goods and passengers), or pax (only carry passengers). The Marine Passenger Shipping Company will provide the base load of the International Tourism Center (the port of the beginning and end of cruises) when it reaches the estimated passenger traffic of more than 100 thousand passengers per year by 2025. Taking into account the fact that 647 thousand people passed passport control in the Seaport in 2019, the new company will be able to increase it by $15 \%$. At the same time, the current capabilities of the customs pavilions have a throughput capacity of up to 2 million people per year (18 thousand people per day).

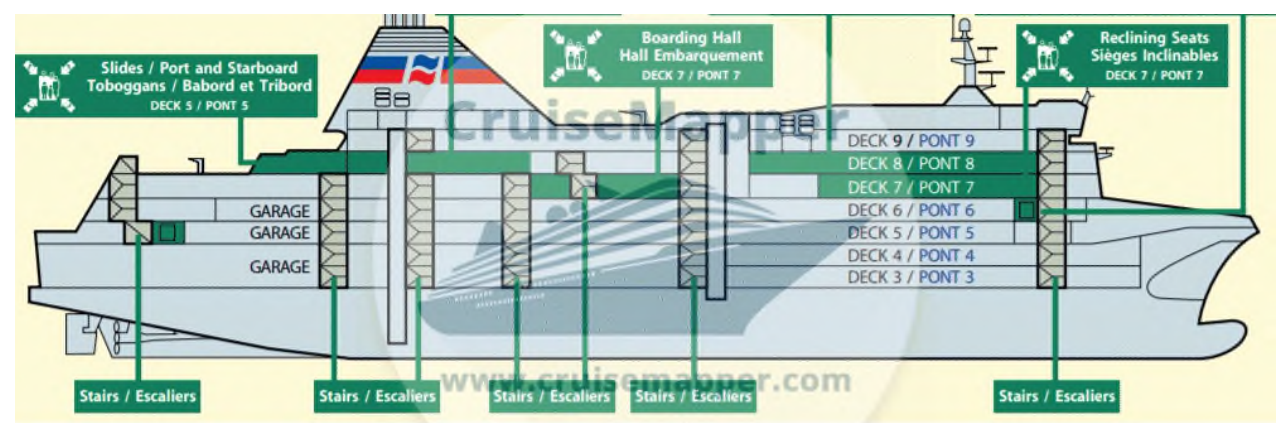

Fig. 3. The enlarged diagram of the layout of zones on a sea ferry for the Baltic region [including residential and entertainment zones at the top desks and several car and cargo desks at the bottom [3].

The total investment in part B is about RUB 27.4 billion, including:

- borrowed funds - $29.9 \%$;

- federal funds - $69.7 \%$;

- funds of the project initiator $-0.4 \%$.

The final total estimated investment in 2019 - 2027 is about 40 billion rubles or about $\$$ 500 million at the current exchange rate for November 2020.

Portrait of the target audience of the project. $85-90 \%$ of the target audience of the project (more than 120 thousand people per year) are citizens of the Russian Federation from St. Petersburg, as well as from the regions of the Central and Volga Federal Districts with an average age of 35-70 years, high and average income, including families with children. At the same time, $10-15 \%$ of the target audience (at least $13-15$ thousand people a year) are foreign tourists (mainly citizens of the USA, Great Britain, Germany), couples and families with children, who are ready to choose the port of the beginning of the end of the cruise in St.Petersburg (incl. for the purpose of visiting the city) and a Russian shipping company.

The largest number of tourists to the Passenger Port comes from Germany - 25\%, followed by tourists from the USA - 19\% and Great Britain - 10\%. Currently, the Passenger Port of St. Petersburg is a transit port; the average stay in St. Petersburg for one cruise tourist is 2 days. In the case of the formation of cruises from St. Petersburg, the period of stay in the city will increase by another 2 days ( 3 days before the cruise and 1 day after), which will significantly increase the volume of income of St. Petersburg from the tourism industry $[1,4]$.

One of the planned socio - economic effects of the project implementation is a more complete filling of commercial objects in related industries - hotel business and HoReCa in 
the whole $[2,3,5]$. The development of the project on the reclaimed territories of Vasilyevsky Island will not only fill the city waterfront, but will also have a generally harmonizing effect on coastal business development, including the Lakhta Center, will give an impetus for development for new public spaces [6, 7, 8] Currently, 107.5 thousand people work in the city's hospitality industry. In related industries - more than 300 thousand people, in the high season - up to 500 thousand people [4]. Thus, up to $15-20 \%$ of the employed and a significant part of the city's business in the strategic plan will benefit from the project.

\section{Discussion}

3.1 Adequacy of the choice of the target audience in the marketing concept of the project. Note that against the background of a decline in investment activity, which is largely due to the crisis in the world economy and politics, as well as the effect of anti-epidemic restrictions, a large investment project in one of the industries affected by the crisis $[9,10$, $11,12]$ looks at first glance unattractive. It seems especially risky to bet on the development of the premium segment of tourism and hospitality associated with the target audience of cruise travel. Indeed, in times of crises, in general, markets and services of "economy class" receive additional development [13].

On the other hand, as the practice of previous years and 2020 shows, and during a period of force majeure investment recession, large investment transactions are concluded aimed at meeting the demand for certain goods and services that are presented by those target audiences of middle-class and above-average consumers who have retained solvency in changed circumstances. In other words, against the background of general crisis phenomena, a number of business areas continue to persist and even develop, focused on those strata of consumers that have retained the same level of income. At the same time, they tend to spend the income they have, including the conditionally additional income in the form of funds not spent in the usual way abroad. These consumer segments are currently of significant importance in ensuring the stability of the functioning of the consumer sectors of the Russian economy [14]. State support for the development of some of the business areas (industries) can have a high multiplier effect on the national economy as a whole.

We also note that, in general, during crisis periods, even against the background of a decline in production in traditional industries, the curtailment of large investments and against the background of general difficulties in the economy, some of the consumers retain the status of the middle class and continue to spend funds, in a certain way changing the direction of their use. For example, in the 1990s, against the background of the general economic recession, trade in a number of imported goods revived in the country, which the majority of the country's inhabitants, despite the crisis conditions and a significant drop in the level of income, were in a hurry to acquire. These included video recorders and household appliances, computers, clothing and furniture, and other goods, mainly imported from abroad. Investments in import trade operations aimed at satisfying the emerging demand for investors had a high yield - from 50 to $200 \%$ per annum and more (The possibility of rapid capital accumulation through such trading operations is confirmed by the fact that those who carried out them formed the business community of "medium-sized businesses" in Russia in the late 1990s - early 2000s, gradually moving from small to ever larger forms business).

According to experts, in the current conditions, which are difficult for the existing industries and types of business, there are market niches associated with the consumption model of the middle class, on which, based on the implementation of consistently built 
marketing concepts, investments have an accelerated payback period. These markets are of interest for investment.

One typical example is the retail market. So, in 2020 in St. Petersburg the chains "Polushka", "Spar", "Semya", "Land", "Yulmart" gave way. However, along with the closure of the stores of these chains, stores of the Magnit, Perekrestok, Pyaterochka, Dixy chains are opening on their premises. Perekrestok and Pyaterochka are striving to provide a more premium service format, and Vkusville is actively developing. Investments in renovation and rebranding to increase consumer flow allow some traditional retail chains to grow despite the growth of distance selling and delivery networks.

Another actual example of investment focused on working with the target audience of the middle and upper strata of the middle class in the current crisis period includes the takeover of the Russian segment of the chain of British hypermarkets Castorama by Maxid by the DIY hypermarket chain (household goods) in September 2020 (transaction amount 7, 4 billion rubles) (Founder and Chairman of the Board of Directors of the Maksidom hypermarket chain, who completed the largest transaction in Russian DIY in the year of the pandemic. URL: https://spb-heroes.rbc.ru/evnevich https://www.rbc.ru/spb_sz/03/11/2020/5fa116a29a7947e1160b9cef (access date 30.11.2020) (in Russian)).

According to the investor, the decision to invest about $\$ 100$ million in the purchase was based on an analysis of consumer behavior in conditions of "remote work" and forced "isolation". The workers who retained their incomes began to invest more in the repair and decoration of housing, the construction of suburban real estate. Representatives of the middle class, freed up as a result of the transition to a remote mode of operation and the closure of tourist borders, began to use the forces and resources to "develop their own territory". Thus, in the context of a pandemic, an investment direction was formed, focused on solvent target audiences, directing additional spending on repairs, finishing and construction.

The above examples, according to the authors, confirm that the selected target audience - namely, not only people with a very high, but also with an average income level, including families with children, can constitute the target audience of the project. However, the marketing concept should be clearly developed techniques and specific forms that will avoid the emergence of contradictions between two potential segments of the target audience with separate satisfaction of the requirements of each segment.

3.2 The influence of political factors on the implementation of plans to attract foreign tourists. Since, according to the calculations of the initiators, from 10 to $15 \%$ of consumers when the project reaches the planned throughput capacity should be foreign tourists, the question is: how much will the flow of tourists from abroad depend on political factors? And also: will the presence of foreign tourists, especially from Europe, be one of the key (defining?) Channels to ensure additional attractiveness of cruise services for domestic tourists?

Let's consider the general composition of factors influencing international tourism. In the standard conditions it consist of: 1) the international cooperation including participation in tourist activities and meetings of state representatives; 2) state policy in the field of tourism including law, economic and transport affordability conditions; 3 ) the factors of political situation including geopolitics.

According to the reporting data of the Committee for the Development of Tourism of St. Petersburg in 2009-2019, regional and state policy in the field of tourism contributed to a significant increase in the number of foreign and domestic tourists visiting the city, up to a record level of about 10.4 million tourists, including 4.9 million foreign, in 2019 [ 4 , p. 10]. In 2009, the number of tourists was 4.9 million, including 2.3 million foreign tourists. The growth in 10 years was 2.1 times. 
The number of passengers of the port of St. Petersburg "Marine Facade" in the period from 2009 to 2019 also more than doubled - from 490.1 thousand people to 1104.5 thousand people (Investment projects. - URL: https: // www .portspb. ru / O_porte / about / invest_programm (date accessed: 30.11.2020)).

However, the state (regional) policy in the field of tourism and even significant achievements in the field of international cooperation are not able to overcome the influence of the factor of geopolitical relations. [15, 16, 17]. In fact, it is necessary to conclude that not only formal restrictions on entry and exit, changes in the general level of income, but also the moral and political characteristics at home of the proposed country of travel and its political leadership has an important influence on the planning of a tourist's trip. In the context of the refusal to include Russia in the countries that are friendly to European and American democracy through the images formed by foreign mass media, the attractiveness of visiting Russia in recent years (after 2014) for European tourists has been reduced.

As a result, despite the general increase in the number of foreign tourists in the city in 2014-2019, the number of tourists from Europe decreased, and the growth was mainly due to the arrival of tourists from China, who have a lower socio-economic and cultural level, as well as sensitive differences in mentality $[12,17]$.

Experience in operating the ferries "Princess Maria" and "Princess Anastasia", which made mini-cruises in 2009-2015. along the routes St. Petersburg - Helsinki and St. Petersburg - Stockholm, in turn, showed that the presence of tourists from Scandinavian countries was an important attractive element for Russian consumers and a factor in increasing the number of spontaneous purchases at the initial stage of the project [3].

Thus, it is possible to conclude that the presence of tourists from developing countries of the Asia-Pacific region on cruises with a low possibility of interaction with them for Russian tourists, which is due to the lack of wide traditions of cultural exchange, seems to be neutral factors or reduce attractiveness. A desirable factor that can have a positive impact on the popularity of the project is an increase in the number of European cruise tourists in St. Petersburg, including from Scandinavian countries, and attracting tourists from the United States.

Increasing the attractiveness of tourists for trips with tourists in the Asia-Pacific region are special events and programs that can develop in the future a convergence in mentality based on cultural exchange [18].

3.3. The influence of internal political factors and factors of the development of an innovative economy on project support at the federal level.

An important component of the cruise tourism project in Russia is the image component, which requires special attention. It is safe to say that the presence of a sea cruise fleet, the ability to provide cruise tourism services from their own passenger ports is a sign of a high level of development of the "consumer society" in this country.

The opening of own cruise routes in the country, as a rule, is associated with the construction of high-level passenger seaports in places of high localization of tourists and ensuring their loading through the popularization of tourist locations. The port "Marine Facade of St. Petersburg" received in 2013 and 2016 prestigious international awards for the best port infrastructure among European cities and cities in the world. Thus, the infrastructure conditions for the opening of the Russian sea cruise line should be considered favorable. The new passenger port of the city during its operation (since 2009) has successfully received foreign cruise ships - from 100 to 260 calls per year.

An important consequence of state aid to business in the period after the 2014 crisis is an increase in the share of state participation in many sectors of the economy, including the financial and banking system $[19,20]$. In the context of limited opportunities for private sector financing of their own projects, including due to the narrowing of the channels for 
attracting foreign financing, the decrease in income during the crisis, the state and the funds created by it become the main creditor.

The shares of JSC Passenger Port of St. Petersburg "Marine Facade", which is the initiator of the project, belong to St. Petersburg and the federal structure involved in the construction and operation of border facilities. The main "engine" of the project is the regional administration of the city. The regional authorities, promoting this project, in particular, count on the attention of the federal center and demonstrate their vision of the prospects for the development of the city and the tourism industry in Russia in general, offering a new type of cruise sea tourism for it. According to the data specified in the description (clause 2.1), the initiator requests about $55.5 \%$ of the total investment volume from federal structures, while the borrowed funds of private companies can only make up about $40 \%$. The share of federal sources $(70 \%)$ is especially high in the construction of a new cruise ship (part B of the project), while for the construction of the Center for International Cruise Tourism the investor expects to receive mainly private funding.

Thus, appealing to the federal center through an application for the implementation of an expensive project that has a positive image effect for the country, the regional administration indicates its high interest and readiness to promote the development of this direction of tourism. Despite the fact that, compared to the tasks of promoting the development of industry and trade, such a project aimed at a high level of consumption by citizens does not seem to be a priority at first glance, the federal authorities can still pay attention to it for a number of economic and domestic political considerations. Here are these considerations:

1) A high degree of interest of the target audience in the context of restrictions on crossborder movements of tourists and the need to invest the surplus of "drop-down foreign expenditures" will have a positive effect on accelerating the payback of the project;

2) Since the new passenger port was recognized as one of the best in the world in terms of manufacturability, including the provision of skippers, further development of the port infrastructure can be integrated into projects for the development of the digital economy and services (digitalization of the urban environment) through the IT sector [21, 22];

3) The construction of Lakhta Center - the tallest building in Europe, reconstruction of the Krestovsky football stadium (Gazprom Arena, Zenit Arena), Western high-speed diameter became important image components of the city-on-Neva development in 20102020 with unique characteristics. The new cruise line project has a coherent nature that can provide synergies in this range.

The commissioning of the Lakhta Center in the coming years may become one of the important factors in the development of the urban economy and tourism. The image component of the completion of the interior decoration and the final opening of a significant object of the urban environment can be widely integrated with the beginning of the operation of the project of international cruise communication in the city.

The full functioning of the cruise communication project in St. Petersburg can get an additional impetus as well as local (and possibly, in the future, global) promotion based on association and integration with such a direction as cinema tourism. Cinema tourism is a relatively new and specialized area of tourism. Today, the category of film tourists can still rather be attributed to niche categories of consumers of tourist services. Nevertheless, in conditions of high competition in the market, taking into account the priorities of the development of domestic tourism, as well as the support of domestic cinematography, which is provided by the state, cinema tourism can become one of the promising and rapidly developing areas of tourism [23, 24].

Cinema tourism destinations can be compared to the main directions of related film production - it can bring together tourists who are interested in history, fantasy and science fiction lovers, connoisseurs of documentary and "alternative" cinema, and in some cases 
fans of TV series and even animation. In addition to the fact that cinema tourists want to visit places where famous films were filmed, they may also tend to visit places where famous historical events took place and which famous people have visited (or lived in). They are interested in special events such as film festivals, festivals based on their favorite films, as well as historical reenactments. These special events, along with physical objects in the region ("landmarks"), can constitute an area of tourist interest for cinema tourists. In St. Petersburg, as well as in satellite cities such as Pushkin, Gatchina, Pavlovsk, in the city of Vyborg and other memorable places of the Leningrad region, there are many objects for film tourism (in addition to historical monuments).

Organized cinema tourism, in addition, can be part of modern technologies for the promotion of film products, which are associated with the so-called trans-media promotion and production of films. In these cases, cinematographers are part of the "game" - a complex idea of the producers to promote the film in alternative ways (in relation to the traditional ways of promotion) $[25,26,27]$. Such promotion technologies can be an effective method, using which travel companies can achieve a synergistic effect.

\section{Results}

As a result of studying various factors that can affect the basic marketing concept of the project for the development of cruise traffic in Russia and the terms of its payback in conditions of anti-epidemic restrictions, the influence of the following factors was revealed (Table 1).

Table 1. Factors of influence on the marketing concept of a cruise line development project and the terms of its payback.

\begin{tabular}{|c|c|c|}
\hline Influencing factors & $\begin{array}{l}\text { Main content. Description. } \\
\text { comments }\end{array}$ & $\begin{array}{l}\text { Assessment of the } \\
\text { degree of influence } \\
\text { in points } \\
(0-10)\end{array}$ \\
\hline \multicolumn{3}{|l|}{ Political } \\
\hline $\begin{array}{l}\text { Long-term political } \\
\text { confrontation with Western } \\
\text { countries. exacerbated in the } \\
\text { period after 2014 }\end{array}$ & $\begin{array}{l}\text { Negative long-term influence on } \\
\text { travel decisions by tourists from } \\
\text { Europe. from the United States due } \\
\text { to anti-Russian rhetoric of the media } \\
\text { and politicians }\end{array}$ & -11.2 \\
\hline $\begin{array}{l}\text { Factors of anti-epidemic } \\
\text { restrictions applied by blocks } \\
\text { of countries in relation to } \\
\text { each other }\end{array}$ & $\begin{array}{l}\text { Restrictions on cross-border } \\
\text { movements of tourists and the } \\
\text { timing of their cancellation are } \\
\text { unpredictable. have a connection } \\
\text { with the political blocking of } \\
\text { countries }\end{array}$ & -9.4 \\
\hline $\begin{array}{l}\text { Domestic political factors of } \\
\text { competition among regional } \\
\text { elites }\end{array}$ & $\begin{array}{l}\text { Possibilities of project coverage on } \\
\text { investment sites that have access to } \\
\text { federal funding sources }\end{array}$ & +3.7 \\
\hline \multicolumn{3}{|l|}{ Economic } \\
\hline $\begin{array}{l}\text { Substitution effect of } \\
\text { "shortfalls in foreign } \\
\text { spending" }\end{array}$ & $\begin{array}{l}\text { In a number of sectors of the } \\
\text { economy. high demand for } \\
\text { "substitutes" (mainly not goods. but } \\
\text { services) of "foreign expenditures" } \\
\text { "warms up" investment activity and } \\
\text { contributes to growth }\end{array}$ & +4.9 \\
\hline Established culture of ferry & To invest in a cruise company's own & +1.2 \\
\hline
\end{tabular}




\begin{tabular}{|l|l|l|}
\hline cruise shipments in the Baltic & $\begin{array}{l}\text { ship. the basic solution is to } \\
\text { maximize passenger space. taking } \\
\text { into account the current level of } \\
\text { development of car rental and car } \\
\text { sharing services in Europe. } \\
\text { Transportation of your own car over } \\
\text { long distances becomes less } \\
\text { attractive }\end{array}$ \\
\hline $\begin{array}{l}\text { Increasing the audience of } \\
\text { tourists from Southeast Asia }\end{array}$ & $\begin{array}{l}\text { In the long term. it is advisable to } \\
\text { adapt the "cultural code" of cruise } \\
\text { travelers to the peculiarities of } \\
\text { tourists from Southeast Asia }\end{array}$ \\
\hline $\begin{array}{l}\text { Integration with the opening } \\
\text { of the "Lakhta Center" and } \\
\text { the direction of cinema } \\
\text { tourism }\end{array}$ & $\begin{array}{l}\text { Successful co-marketing can arouse } \\
\text { increased interest in the project from } \\
\text { the middle class. Possible impact on } \\
\text { more conservative "higher" class } \\
\text { settings }\end{array}$ \\
\hline
\end{tabular}

Note: Table 1 was compiled by the authors on the basis of data from a survey of experts from the tourism industry, marketers and leaders who have implemented investment projects in the tourism business in St. Petersburg (12 professionals were interviewed, including the opinions of the authors). It was proposed to assess the importance of each of the identified factors on a 10-point scale. The coefficient of concordance of expert opinions was $79.3 \%$, the hypothesis of consistency of opinions is accepted.

According to the terms of the survey, each of the points is equivalent to the degree of influence on cash flows and the payback period of the project, which is expressed as a percentage. Thus, the most important influence on the marketing concept of the cruise line development project and the payback period is currently exerted by political factors that generate uncertainty and a share of hostility in relations with Western European partners. According to estimates, this factor reduces the payback indicators by $11.2 \%$ of the conditional value of the payback period and profitability of the project, calculated in the financial model for "normal" conditions - not taking into account those described in Table. 1. factors (recall that in the marketing concept of the project, only $15 \%$ of the number of buyers of cruise services is allocated to the share of foreign tourists).

The next most influential factor, according to experts, is the factor of difficulty and deceleration of the turnover of tourism activities associated with the introduction of antiepidemic restrictions, which will reduce the payback rate by $9.4 \%$. All negative factors, including an increase in the audience of tourists from Southeast Asia, reduce the payback rates by $27.1 \%$.

The influence of positive factors, according to experts, turned out to be less significant. The most significant positive effect will be the replacement of "drop-down foreign expenditures", which will increase the payback rate by $4.9 \%$. The total weight of positive factors will be $11.1 \%$.

As a result, the overall "balance" of the influence of political and economic factors on the payback period of the cruise line development project is negative - "minus 16\%". Thus, we can talk about significant difficulties that the project will face in the new conditions.

\section{Conclusion}

Taking into account the obtained expert data, the conclusion, conclusions and direction of further research should be formulated as follows. It is advisable to develop practical steps to implement a number of measures that are designed to minimize the risks recognized as the most significant. 
1.In order to further involve Western European citizens in cruises organized from St. Petersburg, from the territory of Russia, it is necessary to propose not only a cultural agenda, but also to support current common European and (or) Scandinavian concepts and projects, which primarily include the "green economy","energy saving", "renewable energy sources", as well as "democracy in the new world order", " abandonment of property "in favor of relations of temporary use of goods, such as car sharing, etc. ("equality based on redistribution " according to K. Schwabb [28]). To this end, it is advisable to pre-position St. Petersburg on the European tourist market as a leading city in Russia in a number of the named areas, for example, "green economy", "renewable energy sources".

One of the attractive factors may be more restrained in comparison with the traditional European style for such ships, the decoration of the new cruise liner, its organization (up to the minimization of decoration and interior furnishings of the VIP-class cabins) should emphasize democracy, focus on the middle class and new conditions for co-operation. existence of different segments of the population, supported by a new cruise company from Russia.

In order to gain authority among representatives of the technical intelligentsia in Western countries at the federal and regional levels on a long-term basis, it is advisable to promote large projects of cooperation with European countries in the northern territories, such as the implementation of the international potential of the Arctic cluster [29].

2. It is advisable to offer an active role for interaction with the Chinese tourists arriving in the city to Russian cultural "envoys" ("paladins"). With the aim of mutual adaptation of the mentality of the Chinese and Russians, a greater degree of mutual communication - in particular, during joint cruise trips of Russian and Chinese tourists - it is proposed to form test forms of interethnic communication. This means looking for ways to change the situation when tourists arriving in St. Petersburg from China follow the routes through cafes, restaurants, souvenir shops owned by local "Petersburg" Chinese and do not enter into communication with Russian citizens due to the language barrier.

3. In the context of the new normalcy, which is planned to be preserved in the "postepidemic" world (reduction of direct contacts and cross-border movements of citizens) [28], it is advisable to present the new ferry line as a democratic and safe platform with services that allow citizens of Russia and other countries to "enjoy life "(The ferries" Princess Maria "and" Princess Anastasia ", following from St. Petersburg to the capitals of the Scandinavian and Baltic countries, had a similar image in the first years of their work and in the 2010s.

\section{References}

1. Press release of JSC "Passenger Port of St. Petersburg", https://www.portspb.ru/press_center/news26_old/postid/own_news/9411

2. Materials of the project for the development of the cruise company and the port on the ASI website "Strong Ideas for the New Time", https://idea.asi.ru/users/sign_in?project=improject-48

3. N.N. Mayorov, System analysis and logistics 1(23), 65-73 (2020)

4. Report of the Committee for Tourism Development on the implementation of the state program of St. Petersburg "Development of tourism in St. Petersburg" for 2019 and for the first half of 2020, https://www.gov.spb.ru/gov/otrasl/c_tourism/otchet-napravitelstvo-o-hode-realizacii-gosudarstvennoj-programmy-san/

5. M.A. Pushkina, A.I. Radushinskaya, A.B. Antonova, Bulletin of the National Academy of Tourism 3(51), 60-66 (2019) 
6. D. Radushinsky, A. Radushinskaya, I. Radikov, O. Feoktistova, A. Butyrin, The conference proceedings Business Technologies for Sustainable Urban Development (SPbWOSCE-2017), MATEC Web of Conferences 170, 01043 (2018) DOI: 10.1051/matecconf/201817001043

7. M.G. Vorontsova, A.V. Kuchumov, Bulletin of the National Academy of Tourism 3(51), 14-15 (2019)

8. A.G. Kunitsyna, E.I. Gromovik, I.Yu. Lopatina, Modern Science 6-3, 91-95 (2020)

9. M. Škare, D. Riberio, S. Małgorzata, Porada-Rochoń, Technological Forecasting and Social Change, 120469 (2020) DOI: 10.1016/j.techfore.2020.120469

10. M. Sigala, Journal of Business Research 117, 312-321 (2020) DOI: 10.1016/j.jbusres.2020.06.015

11. N. Güliz Uğur, A. Akbıyık, Tourism Management Perspectives 36, 100744 (2020) DOI: $10.1016 /$ j.tmp.2020.100744

12. I.F. Zhukovskaya, M.V. Krasnova, Business. Education. Right 1(50), 267-272 (2020)

13. E. Bagreeva, A. Mottaeva, E3S Web of Conferences 210, 17024 (2020) https://doi.org/10.1051/e3sconf/202021017024

14. V.A. Shamakhov, Management consulting 4(136), 10-19 (2020)

15. Yu.I. Draisis, E.V. Vidishcheva, A.S. Kopyrin, Bulletin of the Academy of Knowledge 2(37), 99-108 (2020)

16. D. Radushinsky, A. Fedosina and T. Pokrovskaya, Innovative Technologies in Science and Education (ITSE-2020), E3S Web Conf. 210, 13038 (2020) DOI: 10.1051/e3sconf/202021013038

17. Yu.E. Bolotin, G.D. Sanzharova, Problemy sovremennoy ekonomiki (Problems of modern economics) 1(73), 162-166 (2020)

18. I.Yu. Novozhilova, D.A. Tokusheva, Symbol of Science: an international scientific journal 1, 53-60 (2020)

19. S. Banerji, D. Fang, Journal of Corporate Finance 66, 101783 (2020) DOI: 10.1016/j.jcorpfin.2020.101783

20. L. Pushkareva, M. Pushkarev, Innovative Technologies in Science and Education (ITSE-2020), E3S Web Conf., 210, 13041 (2020) DOI: https://doi.org/10.1051/e3sconf/202021013041

21. V. Holodkova, A. Mottaeva, T. Pokrovskaya, E3S Web of Conferences 164, 11043 (2020) https://doi.org/10.1051/e3sconf /202016411043

22. M. Vladimir, I. Sytko, E3S Web of Conferences 164, 08015 (2020) DOI: $10.1051 / \mathrm{e} 3 \operatorname{sconf} / 202016408015$

23. N. Araújo Vila, J. Antonio Fraiz Brea, P. de Carlos, European Research on Management and Business Economics 27(1), $100135 \quad$ (2021) DOI:10.1016/j.iedeen.2020.100135

24. Shashwat Gupta, M.M. Foroudi, Len Tiu Wright, Journal of Business Research 116, 721-733 (2018) DOI: 10.1016/j.jbusres.2018.02.017

25. A. Bec, B. Moyle, K. Timms, Tourism Management 83, 104256 (2020) DOI: 10.1016/j.tourman.2020.10425

26. I. Kapustina, V. Bakharev, S. Barykin, E. Kovalenko, K. Pasternak, E3S Web of Conferences (Key Trends in Transportation Innovation, KTTI 2019) 157, 05009 (2020) DOI: $10.1051 /$ e3sconf/202015705009 
27. V. Lukinov, A. Shlafman, A. Zheltenkov, MATEC Web of Conferences 106, 08073 (2017) DOI:10.1051/matecconf/201710608073

28. K. Schwab, T. Malleret, Covid-19: The Great Reset. Geneve: World Economic Forum (2020) https://straight2point.info/wp-content/uploads/2020/08/COVID-19_-The-GreatReset-Klaus-Schwab.pdf

29. D.A. Radushinsky, Scientific works of the Free Economic Society of Russia 189, 227231 (2014) http://www.iuecon.org/2014/189-veor.pdf

30. E. Ganebnykh, O. Fokina, T. Burtseva, I. Yanov, MATEC Web of Conferences 106, 08082 (2017) 